\title{
La Pinacoteca Civica F. Podesti di Ancona: un laboratorio didattico per la digitalizzazione del Patrimonio
}

\author{
Paolo Clini \\ Ramona Quattrini \\ Renato Angeloni \\ Mirco D'Alessio \\ Laura Lanari
}

Abstract

II Patrimonio Culturale è, a ragione, considerato la maggiore ricchezza di una comunità. Spesso però se ne sottovaluta la fragilità: una caratteristica che si impone invece quando si verifica un evento catastrofico e ne distrugge parte.

Per questa ragione da anni si afferma l'importanza di una documentazione diffusa del Patrimonio Culturale, azione intrapresa in maniera ancora troppo frammentaria e che necessita di una maggiore preparazione dei professionisti, volta alla comprensione e all'uso di tecnologie digitali efficaci, speditive e low-cost.

Questo contributo presenta gli esiti delle attività svolte a tale scopo nell'ambito del laboratorio di Rilievo del corso di laurea in Ingegneria Edile-Architettura dell'Università Politecnica delle Marche, anni accademici 2018-2019 e 2019-2020.

Caso di studio la Pinacoteca Civica "F. Podesti" di Ancona, una delle più importanti collezioni di opere d'arte medievale e moderna della regione Marche.

II lavoro realizzato con gli studenti si è strutturato in 3 fasi: l'analisi guidata delle opere, la digitalizzazione di tali oggetti e dell'ambiente in cui sono esposti, infine l'integrazione degli elaborati prodotti in un Virtual Tour (VT) per garantirne un'agile fruizione.

La validità dei risultati raggiunti è stata ulteriormente evidenziata nel corso dell'emergenza Covid-19, una strutturazione professionale degli output prodotti ha infatti permesso di aprire la Pinacoteca tramite una nuova forma di visita, inclusiva e ricca di contenuti multimediali di alto livello.

Parole chiave

documentazione, riproduzione, didattica, narrazione, Virtual Tour.

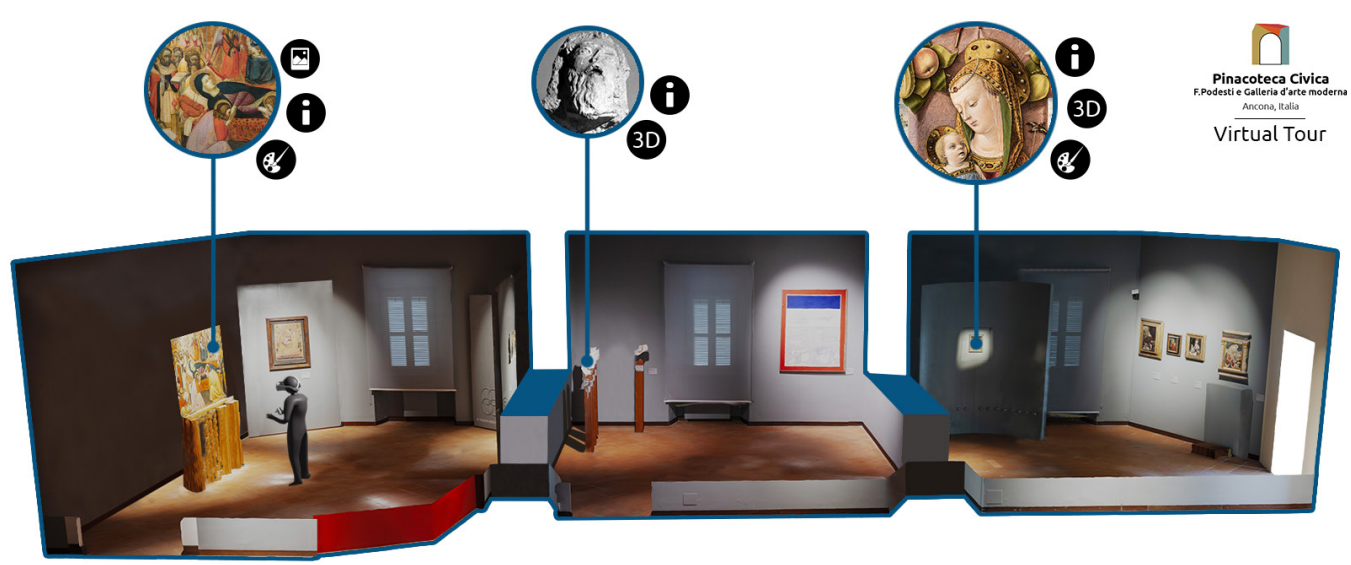




\section{Introduzione}

II Terremoto dell'Emilia nel 20 I2, con il crollo della Torre dei Modenesi a Finale Emilia, il Sisma del Centro Italia nel 2016, con migliaia di beni culturali danneggiati, I'attacco dell'ISIS all'area archeologica di Palmira nel 20 17, l'incendio della Cattedrale di Notre Dame a Parigi, nel 20 I9, sono solo alcune delle più recenti ferite inferte al nostro Patrimonio Culturale.

Preservare la memoria garantendo una documentazione preventiva, che possa essere punto di partenza per una rinascita dei simboli della nostra identità comune, è un dovere cui la nostra società non può venire meno, un impegno per le generazioni attuali e future.

Con l'indizione dell'Anno Europeo del Patrimonio Culturale, iniziativa risalente al 20।8, la Comunità Europea ha voluto sensibilizzare i suoi cittadini proprio alla sua importanza sociale ed economica, ponendo 6 obiettivi generali per la sua tutela: protezione, salvaguardia, riutilizzo, rafforzamento, valorizzazione e promozione [Parlamento Europeo e Consiglio dell'Unione, 20 I 7]; finalità raggiungibili anche grazie all'impiego di strumenti tecnologici. Partendo da questo stimolo, e sulla scia di una linea di ricerca consolidata e che costituisce una cifra del nostro gruppo, si è deciso di sviluppare e rafforzare un apprendimento [I] consapevole delle possibilità offerte dal digitale per la documentazione e la fruizione del Patrimonio Culturale.

Il presente testo analizza tale esperienza che, con l'obiettivo di introdurre nella formazione dei futuri professionisti il tema dell'uso delle tecnologie più performanti per la comprensione dei Beni Culturali a diversa scala, ha raggiunto alcuni esiti significativi. Gli output prodotti hanno costituito infatti la base documentale per il successivo sviluppo di un'esperienza virtuale per un museo civico di medie dimensioni, dimostratasi poi efficace anche nella situazione emergenziale legata al Covid-19.

\section{Stato dell'arte}

\section{II digitale per la documentazione ed il racconto del Patrimonio}

La possibilità di un facile accesso a strumenti di digitalizzazione potenti e veloci ha favorito negli ultimi decenni la tendenza a documentare e fruire del Patrimonio Culturale tramite una visualizzazione virtuale. Rispetto ai tradizionali disegni o plastici, gli output prodotti mediante tale approccio garantiscono infinite possibilità di adattamento a nuove interpretazioni e soluzioni interattive in grado di ampliare la diffusione dei contenuti ad un pubblico potenzialmente illimitato.

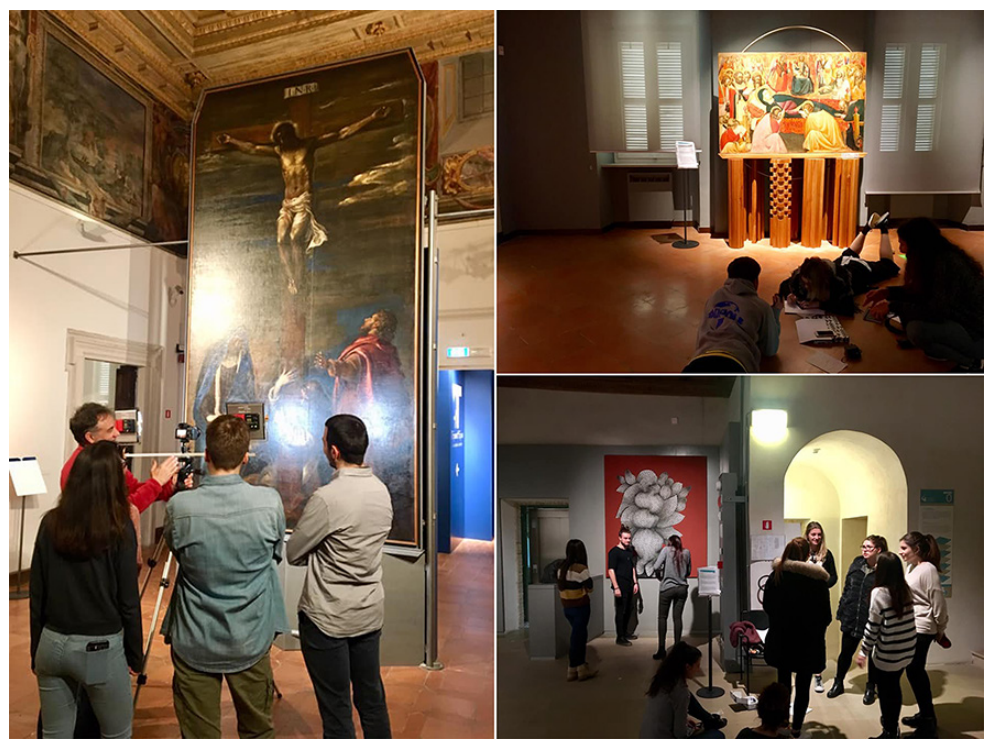


Un approccio metodologico digitale alla documentazione e fruizione del Patrimonio Culturale che non costituisce prassi consolidata per gli operatori di questo settore, il cui lavoro però, a fronte di una loro adeguata preparazione, ne trarrebbe indiscutibilmente enormi benefici.

Soluzioni digitali quali laser scanning [Pfeifer, Briese 2014] e fotogrammetria [Luhtmann et al. $20 \mathrm{ll}$ l] offrono, alla comunità scientifica tanto quanto all'utente comune, la possibilità di una fruizione digitale 3D di singoli beni culturali così come di spazi complessi [liménez Fernández-Palacios et al. 20 I7]; soluzioni ideali per potenziale e versatilità alla documentazione, analisi, visualizzazione e divulgazione del Patrimonio Culturale e declinabili anche per varie finalità didattiche. L'integrazione di queste due tecniche permette infatti di generare modelli 3D fotorealistici e dall'elevato dettaglio geometrico, con metodologie applicabili alle diverse scale e ormai diffusamente accettate come soluzione ottimale per la creazione di facsimili digitali di oggetti o ambienti reali [Clini et al. 20।9; Liang et al. 20।8].

La fruizione di questi output, che hanno già dimostrato enormi potenzialità per la definizione di un esatto piano di monitoraggio, protezione e manutenzione del Patrimonio Culturale, può essere operata attraverso diverse soluzioni, da quelle più comunemente legate ad aspetti divulgativi, come applicazioni di realtà aumentata o virtuale [Bozzelli et al., 20 I9], a veri e propri archivi e cataloghi 3D, come le librerie digitali all'interno dei musei [Clini et al. 20 I 7] o rese disponibili in cloud computing sul web [Quattrini et al. 20 I 8]. Un'ulteriore soluzione che permette di fruire di questi modelli virtuali, integrandoli alla narrazione di aspetti intangibili a loro connessi, è quella offerta dai VT. Come in [Mah et al. 2019], grazie a foto a $360^{\circ}$, questi permettono all'utente di visitare i luoghi della cultura in maniera immersiva ed interattiva, offrendo la possibilità di richiamare contenuti multimediali quali testi, audio e video e di sfruttare un'interazione in tempo reale con operatori addetti alla fornitura di servizi museali. L'ampio potenziale di divulgazione e diffusione delle panoramiche a $360^{\circ}$, che costituisce da anni una consolidata linea di ricerca [Clini, Quattrini 20 I I] e uno standard per i grandi player [Proctor $20 \mathrm{l} \mathrm{I]} \mathrm{non} \mathrm{manca} \mathrm{però} \mathrm{di} \mathrm{riservare} \mathrm{interessanti} \mathrm{sviluppi,} \mathrm{come}$ dimostrato nel presente contributo.

Fig. 2. Vista della nuvola d punti ottenuta dall'allineamento delle 133 scansioni laser eseguite negli

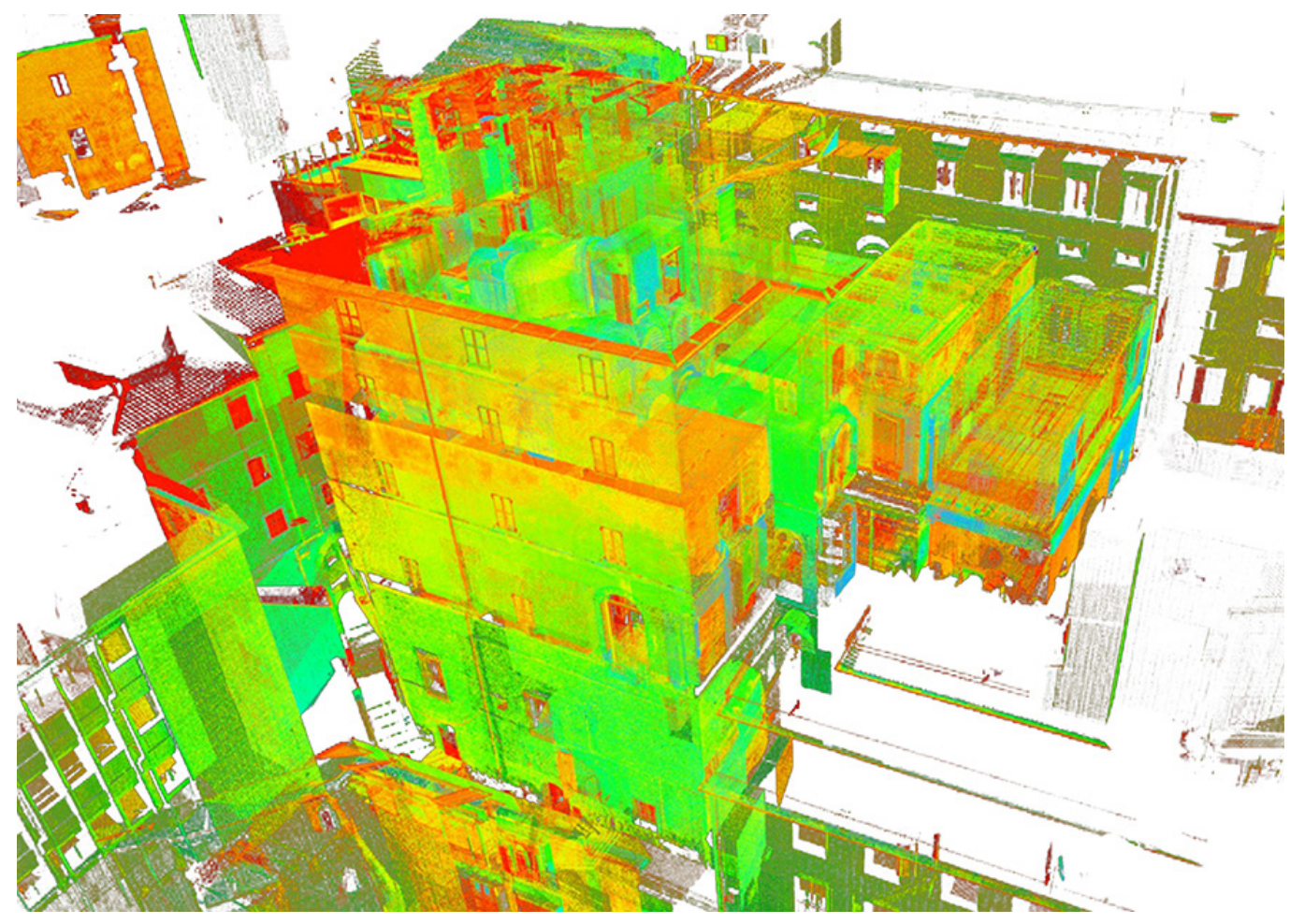


Fig. 3. Individuazione degli scatti di acquisizione per la copertura dell'edificio, progetto di presa e vista 3D della dense cloud elaborata.

\section{Metodologia}

La Pinacoteca Civica F. Podesti di Ancona: un laboratorio didattico per la digitalizzazione del Patrimonio

II laboratorio di Rilievo del corso di laurea in Ingegneria Edile-Architettura dell'Università Politecnica delle Marche, con la sua esperienza di pratica sul campo, integra le lezioni frontali tenute in aula e finalizzate all'apprendimento delle basi teoriche di questa disciplina. II corso, nelle varie edizioni, ha dislocato le sue attività nei principali luoghi della cultura del territorio marchigiano, nella convinzione che il confronto diretto con il Patrimonio Culturale possa essere uno stimolo concreto ed un momento di responsabilizzazione per gli studenti, che diventeranno i professionisti del domani.

Per gli anni accademici 2018-2019 e 2019-2020 il caso di studio scelto è la Pinacoteca Civica "F. Podesti" di Ancona, riferimento nella scena culturale del capoluogo marchigiano sin dall'istituzione, avvenuta nel I 884. L'edificio che oggi ospita la sua collezione è lo storico Palazzo Bosdari, edificato nell'attuale conformazione già nel 1400 e ristrutturato a partire dal 1660, con accenti fortemente manieristici.

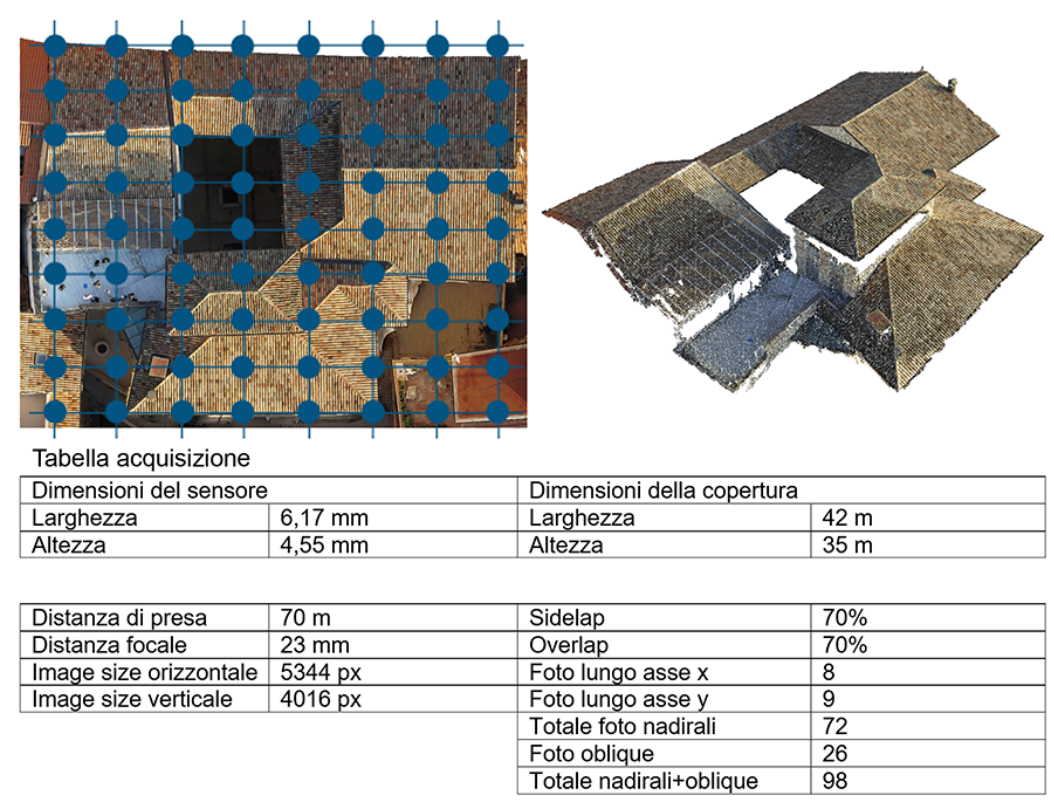

Digitalizzare contenuto e contenitore

Il lavoro ha previsto una prima fase di conoscenza degli oggetti, avvenuta tramite il racconto dell'edificio e l'approfondimento di alcune opere esposte da parte degli storici dell'arte della cooperativa Le Macchine Celibi, che si occupa della gestione del Museo e che ha attivamente partecipato alle attività condotte. Gli studenti, conosciuta la storia, le caratteristiche e le conseguenti problematiche legate a spazi e oggetti, sono stati contemporaneamente attori e discenti nella seconda fase prevista: la digitalizzazione mediante laser scanner e fotogrammetria delle opere loro assegnate e dei relativi spazi espositivi. L'obiettivo principale di ogni gruppo è stata quindi la definizione di un set completo di informazioni geometriche e non solo, utili a definire un perfetto facsimile digitale di una porzione di edificio e di quanto in esso contenuto.

Ai fini della documentazione dell'edificio sono state eseguite I 33 stazioni di presa impiegando una ScanStation Leica P40, integrate con foto a $360^{\circ}$, elaborate a partire da 8 singoli scatti eseguiti con una fotocamera Nikon D90 dotata di obiettivo fisheye da $8 \mathrm{~mm}$, montata su testa panoramica e posta su treppiede in modo da farne collimare il centro nodale con il sensore del laser. Per ottenere un modello completo della struttura, ricorrendo ad un drone Parrot Anafi, si è quindi eseguito il rilievo aerofotogrammetrico delle coperture. Un gruppo di studenti è stato coinvolto nella pianificazione del volo, poi condotto con l'assistenza di un operatore SAPR qualificato [2]. 
L'attività di digitalizzazione ha infine interessato le opere, in questo caso eseguita applicando la tecnica fotogrammetrica Structure from Motion. Ciascun gruppo di studenti si è concentrato su quelle relative alle sale espositive di cui si erano precedentemente occupati nella fase di rilievo dell'architettura. Per un'adeguata successiva ricostruzione tridimensionale, l'acquisizione ha visto l'impiego di un idoneo sistema di luci, schermate con pellicole polarizzanti al fine di eliminare riflessi superficiali mediante la rotazione di un analogo filtro applicato all'obiettivo della fotocamera, una Sony $\alpha 9$ (fig. I).

Questa enorme mole di dati è stata quindi elaborata ricorrendo a diversi software (sw). Per quanto derivante dalle scansioni laser è stato impiegato il sw Leica Cyclone, le nuvole di punti relative a ciascuna presa sono state allineate ottenendo un unico modello discreto, descrivente tutti gli spazi della Pinacoteca, costituito da oltre 9 miliardi di punti (fig. 2), colorati ricorrendo alle immagini panoramiche a $360^{\circ}$ prodotte grazie al sw PTGui, con un errore di allineamento finale dell'ordine del centimetro.

L'elaborazione, all'interno del software Agisoft PhotoScan, delle acquisizioni da drone (fig. 3) ha permesso quindi di integrare tale nuvola di punti con quella relativa alla copertura dell'edificio (fig. 4).

L'output finale è stato decimato per poter essere agilmente gestito dai gruppi di studenti ai fini dell'estrapolazione di piante, prospetti e sezioni dell'edificio (fig. 5).

Per le diverse opere, gli scatti fotografici acquisiti in formato raw, sono stati editati grazie al sw Adobe CameraRaw, e quindi anch'essi elaborati in PhotoScan ottenendone dei modelli 3D con un errore di allineamento massimo stimato pari ad I mm (fig. 6).

L'ultimo passaggio di questo processo di digitalizzazione è stata la ricongiunzione di contenuto e contenitore: ciascuna delle opere è stata portata nel sistema di riferimento spaziale della nuvola di punti dell'edificio associando le coordinate di punti noti dalle scansioni laser ai corrispondenti ottenuti mediante processo fotogrammetrico. Risultato finale è l'esatta riproduzione geometrica dell'edificio, integrata con modelli delle opere di elevato dettaglio e soprattutto caratterizzati da texture fotografiche ad alta risoluzione (fig. 7).

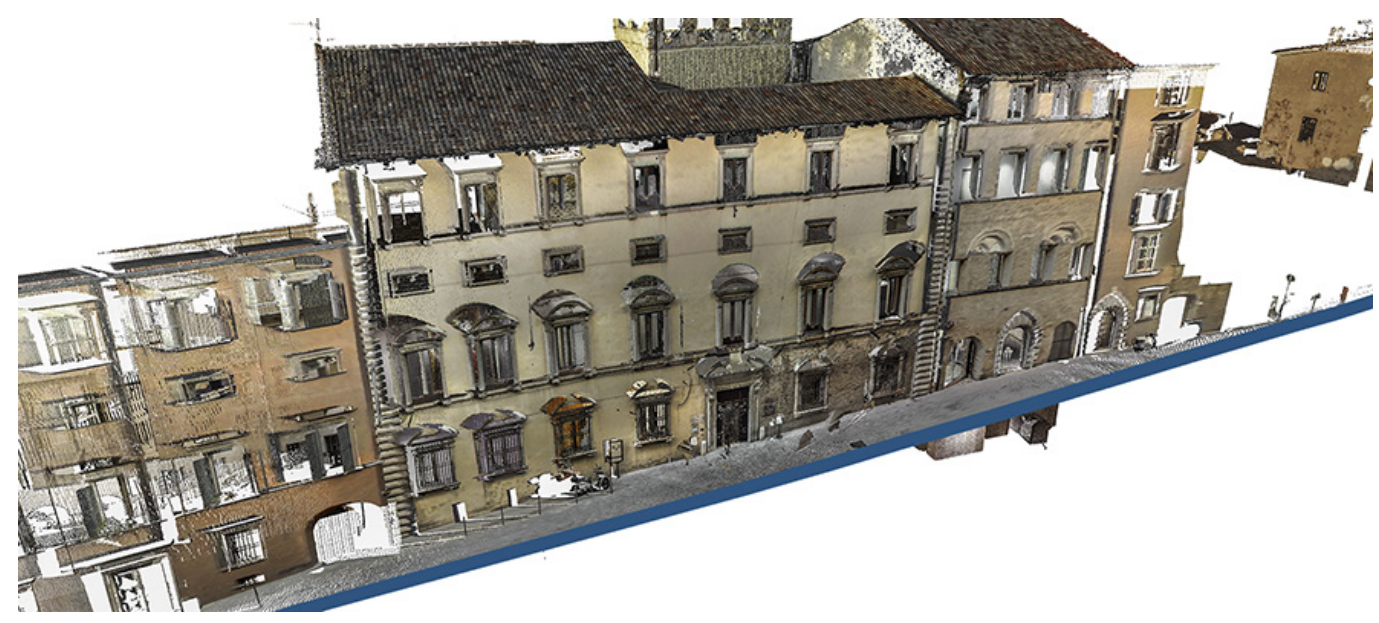

Un tour virtuale per comunicare il Patrimonio

Gli esiti della descritta esperienza didattica sono stati ulteriormente valorizzati dall'attivazione di una riflessione congiunta tra i ricercatori dell'Università Politecnica delle Marche e gli interlocutori del Museo.

La riflessione interdisciplinare ha condotto il gruppo di lavoro alla messa a sistema di una progettualità più ampia rivolta alla creazione di un prodotto digitale dalle spiccate potenzialità interattive ed esperienziali. 

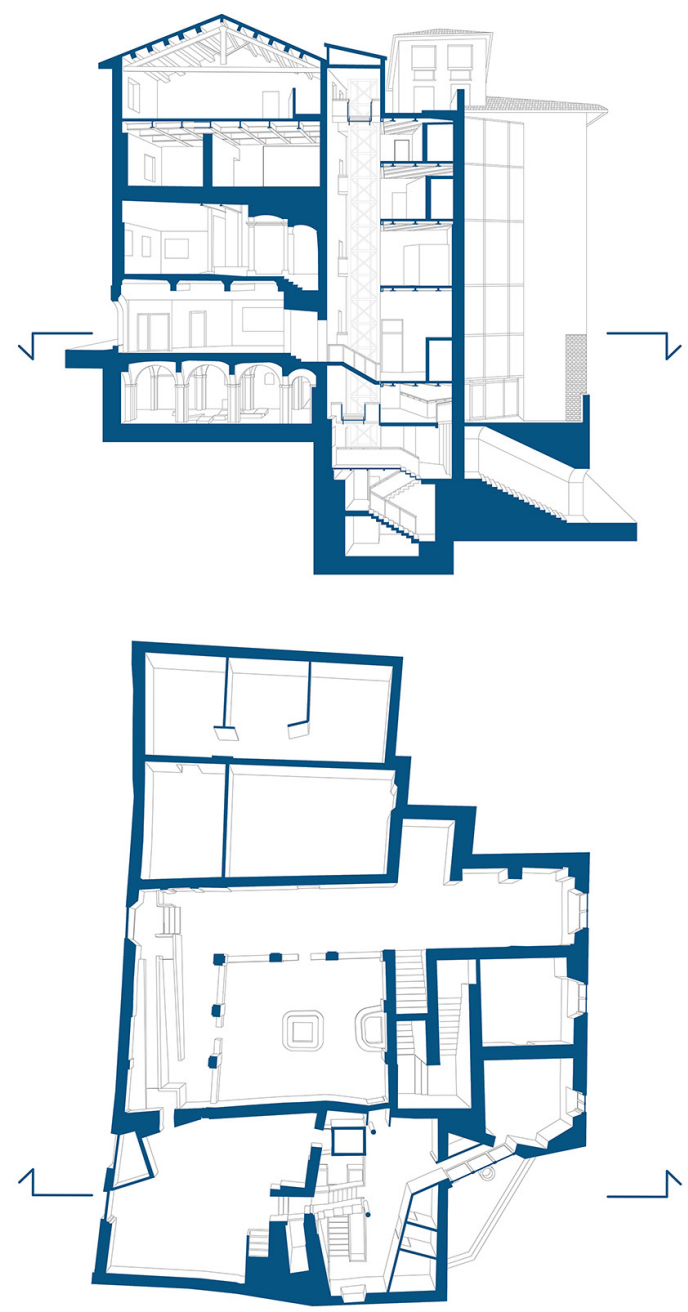

Il valore aggiunto di questa esperienza si può ricondurre ad un duplice contributo:

- II primo riguarda l'attivazione del dialogo museologia-tecnologia. Nel settore museale è infatti molto carente la percezione consapevole delle potenzialità connesse al mondo degli strumenti tecnologici. Questa esperienza ha dunque creato un ponte tra i due settori, con l'avvio di una progettazione a lungo termine che vede l'arricchimento del percorso degli studenti e allo stesso tempo la connessione dell'Università al territorio a sostegno del Patrimonio Culturale.

- Il secondo ha riguardato la creazione di uno strumento operativo a disposizione del museo. Questo strumento permette di rivolgersi al pubblico virtuale e può essere utilizzato per nuove forme di fruizione e catalogazione digitale del patrimonio.

L'approccio progettuale intrapreso ha quindi mirato alla realizzazione di un prototipo di "museo digitale empatico" [Vitale, 20 I3] secondo un concetto che mette al centro la persona seguendo un preciso schema:

- indagare l'utenza del museo;

- porre le condizioni per motivare le persone all'interazione con il patrimonio museale;

- attivare ambienti che abilitino la partecipazione attraverso la cura dei diversi linguaggi per ogni target di pubblico individuato.

Queste premesse hanno fatto in modo che il progetto rivolgesse la sua attenzione nei confronti dell'esperienza museale; questa può dirsi ottimale quando c'è focalizzazione e attenzione ai processi in atto, interesse affettivo, appagamento e gioia, e quindi motivazione perché in questo stato l'utente percepisce che ciò che sta facendo è base e ragione della sua azione. 
Fig. 6. Elaborazione fotogrammetrica della Pala Gozzi, prima opera datata del Tiziano.
Fig. 7. Integrazione della nuvola di punti dell'edificio con i modelli mesh delle opere Vista della Pala Gozzi esposta nella Sala Zampetti.

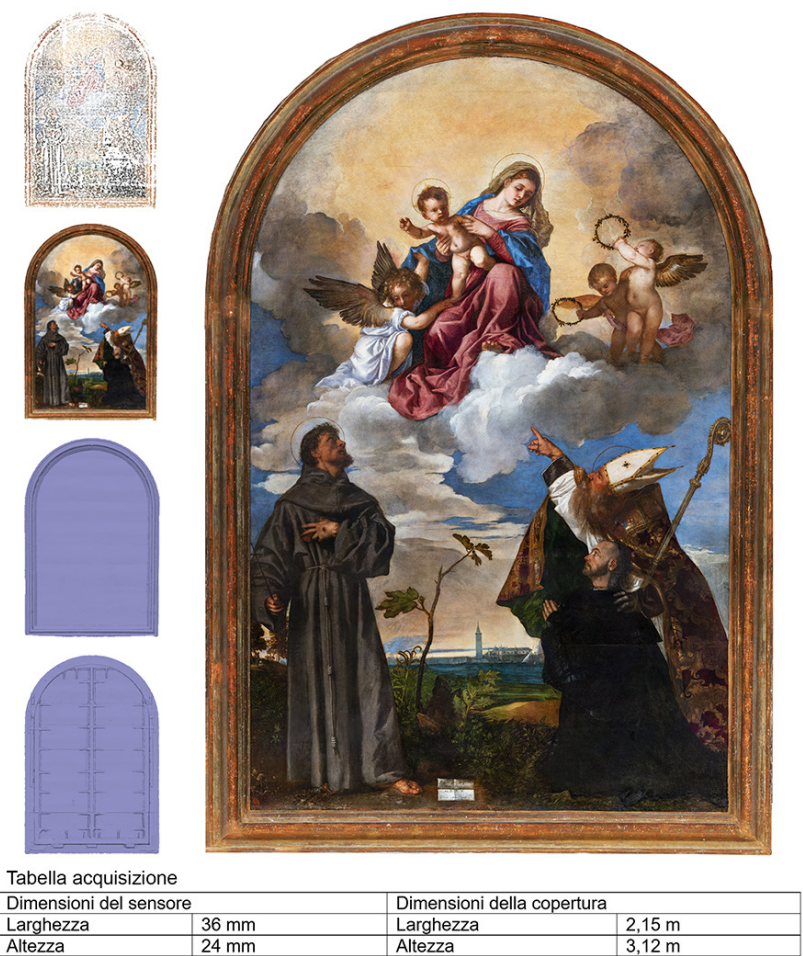

Allezza

\begin{tabular}{|l|l|l|l|}
\hline Distanza di presa & $1,5 \mathrm{~m}$ & Sidelap & $70 \%$ \\
\hline Distanza focale & $50 \mathrm{~mm}$ & Overlap & $70 \%$ \\
\hline Image size orizzontale & $6000 \mathrm{px}$ & Foto lungo asse $\mathrm{x}$ & 7 \\
\hline Image size verticale & $4000 \mathrm{px}$ & Foto lungo asse y & 15 \\
\hline
\end{tabular}

\begin{tabular}{|l|l}
\hline Image size verticale $4000 p x$ \\
\hline
\end{tabular} Totale foto

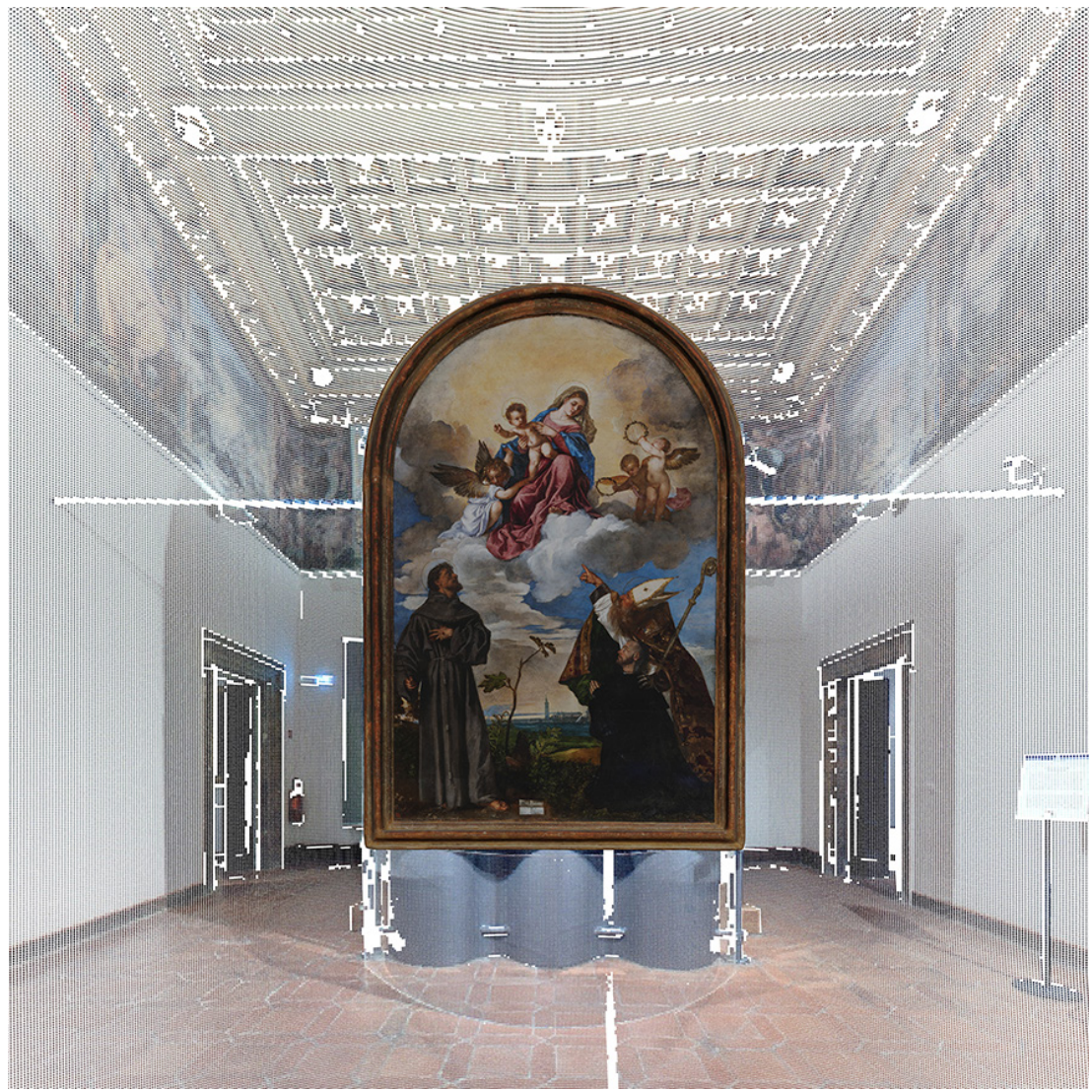


Fig. 8. Schema concettuale che relaziona esperienza diretta del Patrimonio Culturale ed esperienza remota: il Tou Virtuale, grazie a diversi contenuti multimedial, struttura un adeguata narrazione e riproduce luoghi e oggetti.
Alla base della fruizione si trova quindi la motivazione che può essere ricondotta a 4 driver fondamentali secondo [Morris, 2004]:

1) L'aspetto sociale come forma di intrattenimento;

2) L'aspetto intellettuale per fini accademici e professionali;

3) L'aspetto emozionale legato all'esperienza estetica;

4) La dimensione spirituale che insiste sulla creatività e sui processi contemplativi.

Un buon museo, soprattutto virtuale, non deve scoraggiare e deve essere facilmente accessibile, con indicazioni comprensibili e con informazioni utili, studiate per ogni tipologia di pubblico [Branchesi et al., 2016].

A questo proposito il VT realizzato ha messo in atto una serie di modelli per sperimentare come raggiungere un'adeguata interazione con il pubblico, con l'intento di riproporre le dinamiche proprie dell'esperienza diretta del Patrimonio Culturale (fig. 8).

II VT, elaborato partendo dalle potenzialità offerte dal software Pano2VR, permette all'utente di spostarsi da una sala all'altra grazie ad una mappa della Pinacoteca o selezionando direttamente un'opera di suo interesse. In ogni ambiente è presentato automaticamente un testo introduttivo ai dipinti esposti e cliccando su di essi è possibile richiamarne informazioni, immagini ad alta risoluzione e modelli 3D (fig. 9).

Inoltre, indossando un visore per la realtà virtuale, è possibile avviarne un'esperienza completamente immersiva per una riproduzione tridimensionale di spazi e opere (fig. I0).

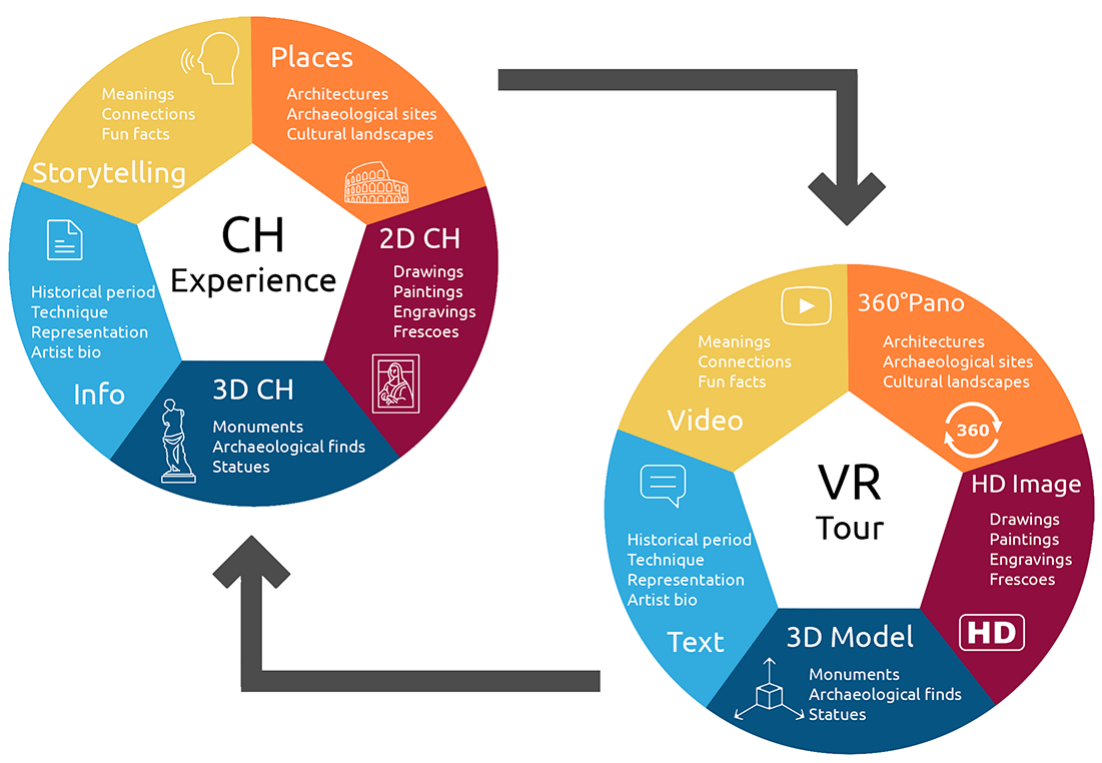

\section{Conclusioni e sviluppi futuri}

La progettualità avviata si costituisce come un laboratorio di sperimentazione permanente che permetterà di lavorare sul VT con l'obiettivo di potenziare e aggiungere strumenti rivolti alla cura della relazione con le persone.

Di seguito alcuni esempi di implementazione, strutturati in riferimento a temi specifici, che potranno essere messi a sistema:

- Accessibilità: si prevede lo studio e la realizzazione di appositi strumenti di mediazione come testi ad alta leggibilità, audio descrittivi e narrativi pensati per diverse tipologie di utenza.

- Intrattenimento: sarà definito un palinsesto connesso all'uso dello spazio virtuale caratterizzato da visite guidate e mostre, con esposizioni di opere che difficilmente sarebbero stati esposti nella dimensione reale. 
Fig. 9. II tour virtuale fornisce informazion sulle diverse sale $e$ approfondimenti sulle singole opere implementando immagin ad alta risoluzione e modelli 3D.
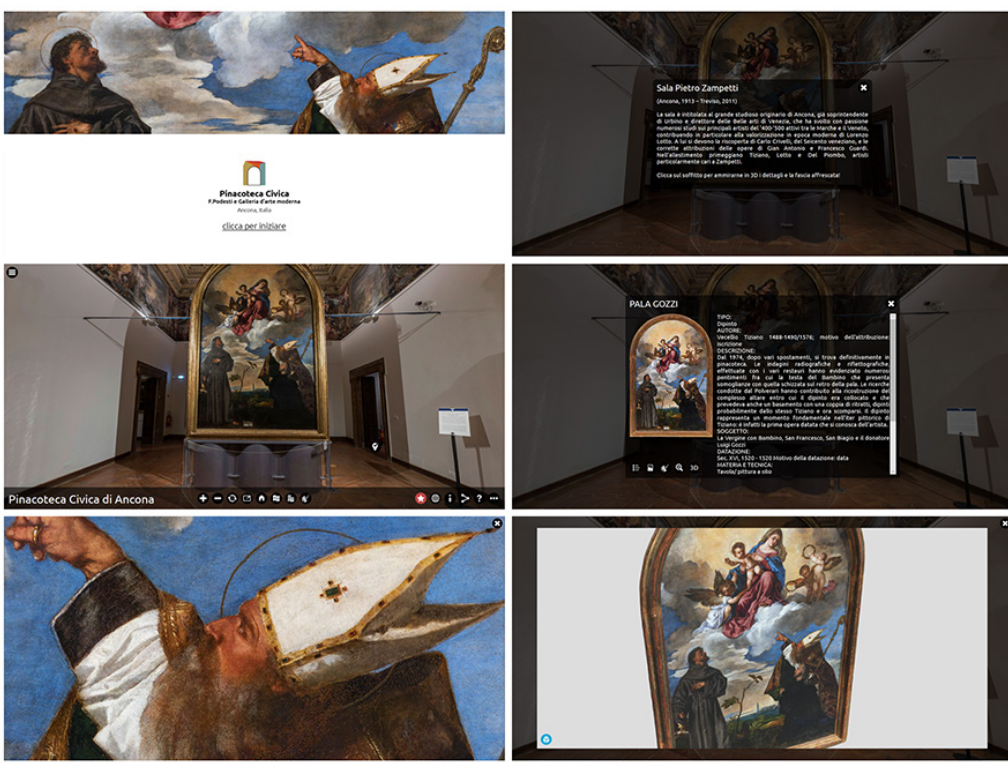

- Fruizione: si integreranno proposte rivolte all'esplorazione di singole opere con aggiunta di schede tematiche. Ad esempio, gli aspetti legati al restauro offrirebbero la possibilità di indagare la realtà materica dei dipinti.

La grande sfida di questo approccio è la dimostrazione di come la tecnologia può entrare nel mondo della fruizione dei beni culturali realizzando supporti che, a partire da una corretta digitalizzazione del patrimonio quale nuova forma di tutela e conservazione, implementino la funzione educativa mettendo in atto nuovi sistemi di interazione e possibili servizi rivolti al nuovo pubblico virtuale.

Fig. 10. Utilizzo di visore per la realtà virtuale per un'esperienza immersiva delle sale e che permette di richiamare i modelli 3D delle opere in scala |:l.
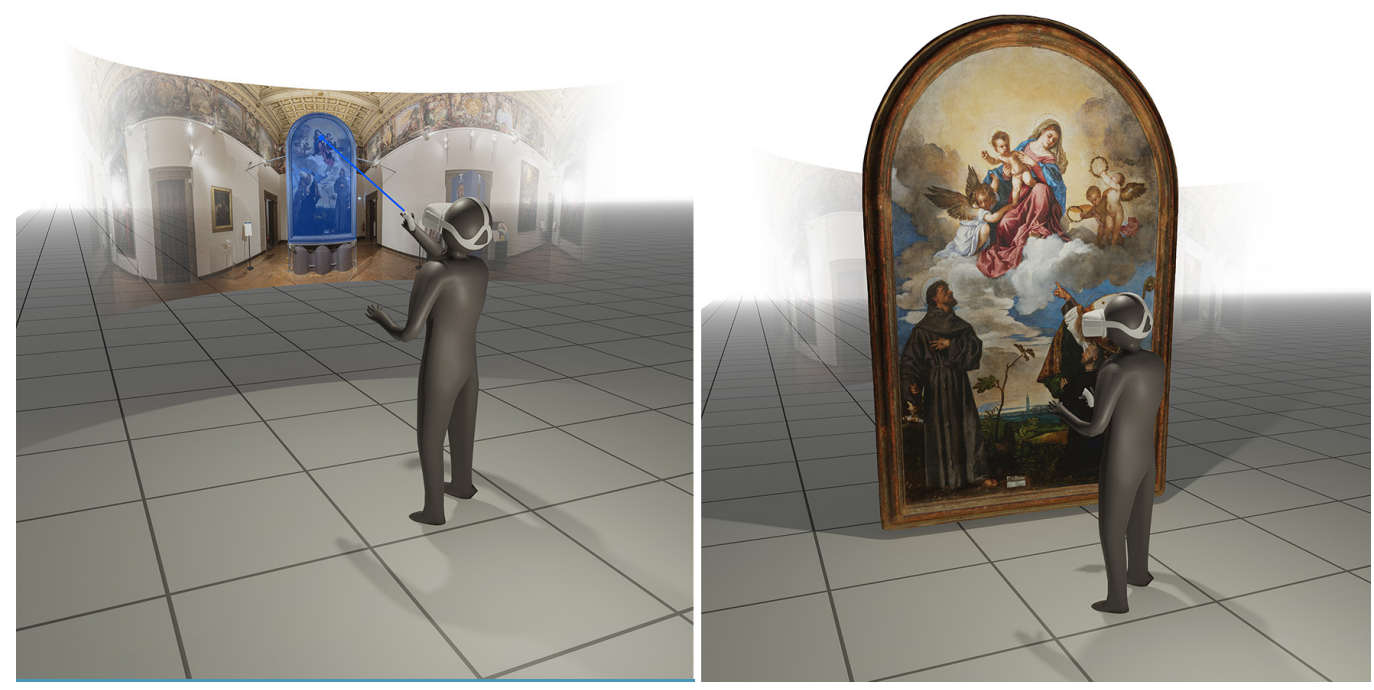

Note

[I] L'attività didattica è stata sviluppata all'interno del laboratorio di Rilievo del corso di laurea in Ingegneria Edile-Architettura dell'Università Politecnica delle Marche, Prof. Paolo Clini.

[2] L'acquisizione mediante drone è stata condotta dal Dott. Ing. Gianluca Gagliardini, professionista esperto di rilievo laser scanning e fotogrammetrico e coadiutore didattico del corso. 


\section{Riferimenti bibliografici}

Bozzelli Guido, Raia Antonio, Stefano Ricciardi et.al. (2019). An integrated VR/AR framework for user-centric interactive experience of cultural heritage:The ArkaeVision project. In: Digital Applications in Archaeology and Cultural Heritage, Vol. 15.

Branchesi Lida, CurziValter, Mandarano Nicolette (20 I6). Comunicare il museo oggi. Dalle scelte museologiche al digitale. Milano: Skira editore.

Clini Paolo et.al., (2019). The integrated survey of narrow spaces and underground architecture:The case study of Campana caves bas-reliefs. In: ISPRS Annals of the Photogrammetry, Remote Sensing and Spatial Information Sciences. S.I.: s.n.

Clini Paolo, Nespeca Romina, Ruggeri Ludovico (2017). Virtual in real. Interactive solutions for learning and communication in the national archaeological museum of Marche. In: International Archives of the Photogrammetry, Remote Sensing and Spatial Information Sciences - ISPRS Archives. S.I.: s.n., p. 647-654.

Clini Paolo, Quattrini Ramona (20I I). Le panoramiche sferiche per il rilievo e la comunicazione dell'architettura, un nuovo approccio alla realtà virtuale speditiva. In: Sardo Nicolò (a cura di). Metodologie integrate per il rileivo, il disegno, la modellazione dell'architettura e della città. Roma: Gangemi Editore.

Jiménez Fernàndez-Palacios Belen, Morabito Daniele, Remondino Fabio (2017). Access to complex reality-based 3D models using virtual reality solutions. In: Journal of Cultural Heritage.Vol. 23, p. 40-48.

Liang Huilin et al. (20/8). The integration of terrestrial laser scanning and terrestrial and unmanned aerial vehicle digital photogrammetry for the documentation of Chinese classical gardens - A case study of Huanxiu Shanzhuang, Suzhou, China. In: Journal of Cultural Heritage, nr 33, pp. 222-230.

Luhtmann Thomas, Robson Stuart, Kyle, Harley lan (201 I). Close Range Photogrammetry: Principles, techniques and applications S.I.: s.n.

Mah Osten Bang Ping et al. (2019). Generating a virtual tour for the preservation of the (in)tangible cultural heritage of Tampines Chinese Temple in Singapore. In: Journal of Cultural Heritage, nr. 39, pp. 202-21 I.

Morris Gerri (2004). It's a vision thing: <https://www.culturehive.co.uk/wp-content/uploads/20 I 3/09/Its-a-vision-thing...GerriMorris.2004.pdf. $>$.

Parlamento europeo e Consiglio dell'Unione (2017). Decisione (UE) 2017/864 del Parlamento europeo e del Consiglio de 17 maggio 2017 relativa a un Anno europeo del patrimonio culturale (2018). Unione Europea: Gazzetta ufficiale dell'Unione europea: <https://eurlex.europa.eu/legalcontent/IT/TXT/PDF/?uri=CELEX:320 I7D0864\&from=EN>.

Pfeifer Norbert, Briese Christian (20 I 4). Laser scanning - principles and applications. In: GeoSiberia 2007 - International Exhibition and Scientific Congress. S.I.: s.n.

Proctor Nancy (20 I I).The Google Art Project:A New Generation of Museums on the Web? In: Curator:The Museum Journal.

Quattrini Ramona, Frappicini Nicoletta, et Nespeca Romina (20 I8). ARCHEOGate: un portale web per la catalogazione e la fruizione dell'archeologia delle Marche. In: Salerno Rossella (ed.). Rappresentazione materiale/immateriale-Drawing as (in)tangible representation. $40^{\circ}$ Convegno internazionale dei docenti delle discipline della rappresentazione. Milano I 5 - I7 settembre 20 I 8 : Milano: Gangemi Editore, pp. I349-1358

Vitale Giovanna (20I3). Design di sistema per le istituzioni culturali. II museo empatico. Bologna: Zanichelli <http://wmw.aiap.it/ libreria.php?|D=6227>

\section{Autori}

Paolo Clini, Università Politecnica delle Marche, p.clini@univpm

Ramona Quattrini, Università Politecnica delle Marche, r.quattrini@univpm.it

Renato Angeloni, Università Politecnica delle Marche, r.angeloni@pm.univpm.it

Mirco D'Alessio, Università Politecnica delle Marche, m.dalessio@pm.univpm.it

Laura Lanari, Macchine Celibi soc. coop. , lauralanari@museieducativi.it

Per citare questo capitolo: Clini Paolo, Quattrini Ramona, Angeloni Renato, D'Alessio Mirco, Lanari Laura (2020). La Pinacoteca Civica F. Podesti di Ancona: un laboratorio didattico per la digitalizzazione del Patrimonio/The Civic Art Gallery of Ancona: an educational laboratory for the digitization of Cultural Heritage. In Arena A., Arena M., Brandolino R.G., Colistra D., Ginex G., Mediati D., Nucifora S., Raffa P. (a cura di). Connettere. Un disegno per annodare e tessere. Atti del $42^{\circ}$ Convegno Internazionale dei Docenti delle Discipline della Rappresentazione/Connecting Drawing for weaving relationships. Proceedings of the 42th International Conference of Representation Disciplines Teachers. Milano: FrancoAngeli, pp. $1794-1993$. 


\title{
The Civic Art Gallery of Ancona: an Educational Laboratory for the Digitization of Cultural Heritage
}

\author{
Paolo Clini \\ Ramona Quattrini \\ Renato Angeloni \\ Mirco D'Alessio \\ Laura Lanari
}

Abstract

Cultural Heritage is considered as the greatest wealth of a community. However, its fragility is underestimated and it becomes evident only when a catastrophic event occurs destroying part of it. For this reason, in years it is asserted the importance of a widespread documentation of the Cultural Heritage, action taken in a way that today is still too fragmentary and that requires a greater training of experts, aimed at understanding and using effective, fast and low-cost digital technologies.

This contribution presents the results of the activities carried out with this aim in the context of the Architectural Survey Lab of the degree course in Building Engineering-Architecture of the Polytechnic University of Marche, academic years 201 8-2019 and 2019-2020.

The case study is the Civic Art Gallery "F.Podesti" of Ancona, one of the most important collections of medieval and modern art of the Marche region.

The work carried out with the students was structured in 3 phases: the guided analysis of the works, the digitalization of these objects and of the environment in which they are exhibited, finally the integration of the elaborated products in a Virtual Tour (VT) to ensure an agile fruition.

The emergency Covid- 19 highlighted the validity of the results achieved, a professional organization of the outputs has allowed to open the Art Gallery through a new form of visit, inclusive and rich in high quality multimedia contents.

Keywords

documentation, reproduction, didactics, storytelling, virtual tour.

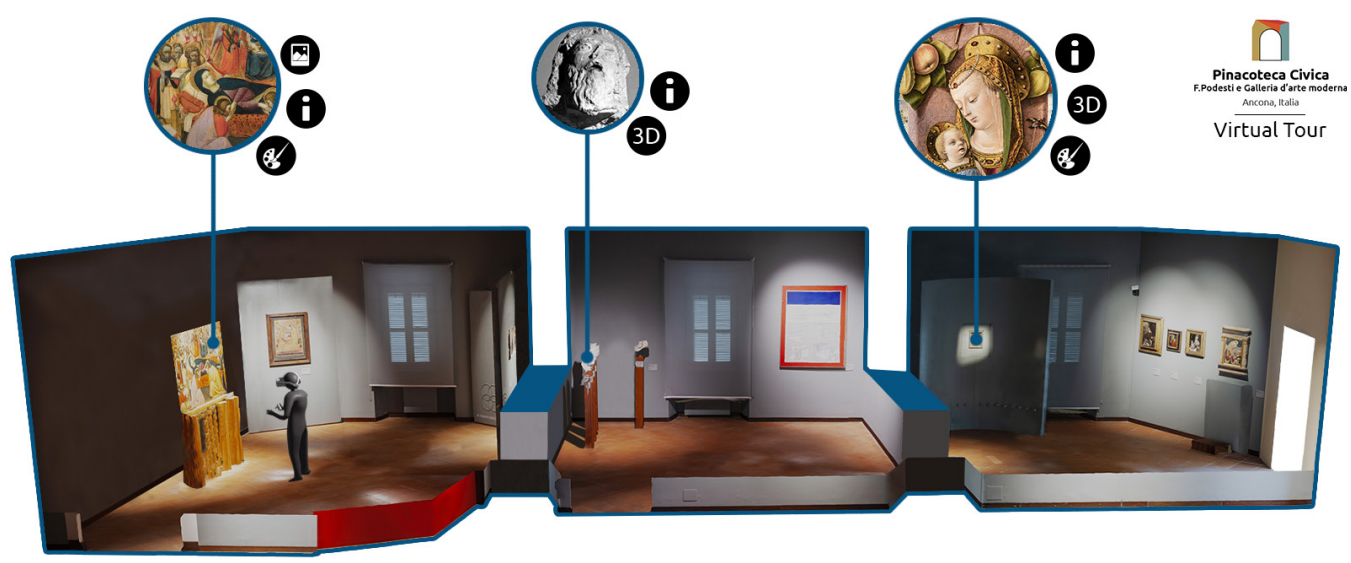




\section{Introduction}

The Emilia earthquake in 2012, with the collapse of the Torre dei Modenesi in Finale Emilia, the Earthquake of Central Italy in 2016, with thousands cultural assets damaged, the ISIS attack to the archaeological area of Palmira in 2017, the fire at Notre Dame Cathedral in Paris in 2019 are some of the most recent wounds inflicted on our Cultural Heritage.

Preserving the memory by ensuring a preventive documentation, which can be a starting point for a rebirth of the symbols of our common identity, it is a duty that our society cannot fail and it is a commitment for current and future generations.

In 2018 the European Year of Cultural Heritage was announced, in this occasion The European Community aimed at raising its citizens' awareness on its social and economic importance, setting 6 general objectives for its preservation: protection, safeguard, reuse, strengthening, valorisation and promotion [European Parliament and Council of the Union 20 I 7]; goals attainable also thanks to the use of technological tools. Starting from this stimulus, and thanks to a well-established line of research, which is a fundamental point of our research group, we decided to develop and strengthen a learning [I] aware of the possibilities offered by digital documentation and fruition of the Cultural Heritage.

The present text analyses this experience, characterized by the aim of introducing into the training of future professionals the theme of the use of the best performing technologies to understand the Cultural Heritage at different scales, and it shows how some significant results has been reached. The outputs were in fact the documentary basis for the subsequent development of a virtual experience for a medium-sized civic museum, which proved effective also in the emergency related to the Covid- 19.

\section{State of Art}

Digital for the documentation and the narration of Cultural Heritage In the last few decades, the possibility of easy access to powerful and fast digitisation tools has favoured the tendency to document and enjoy the Cultural Heritage through virtual visualization. Compared to traditional drawings or models, the outputs produced through this approach guarantee endless possibilities to adapt to new interpretations and interactive solutions that can extend the dissemination of content to a potentially unlimited audience. A digital methodological approach to the documentation and use of Cultural Heritage is not a well-established practice for operators in this sector, whose work, however, would unquestionably reap enormous benefits.

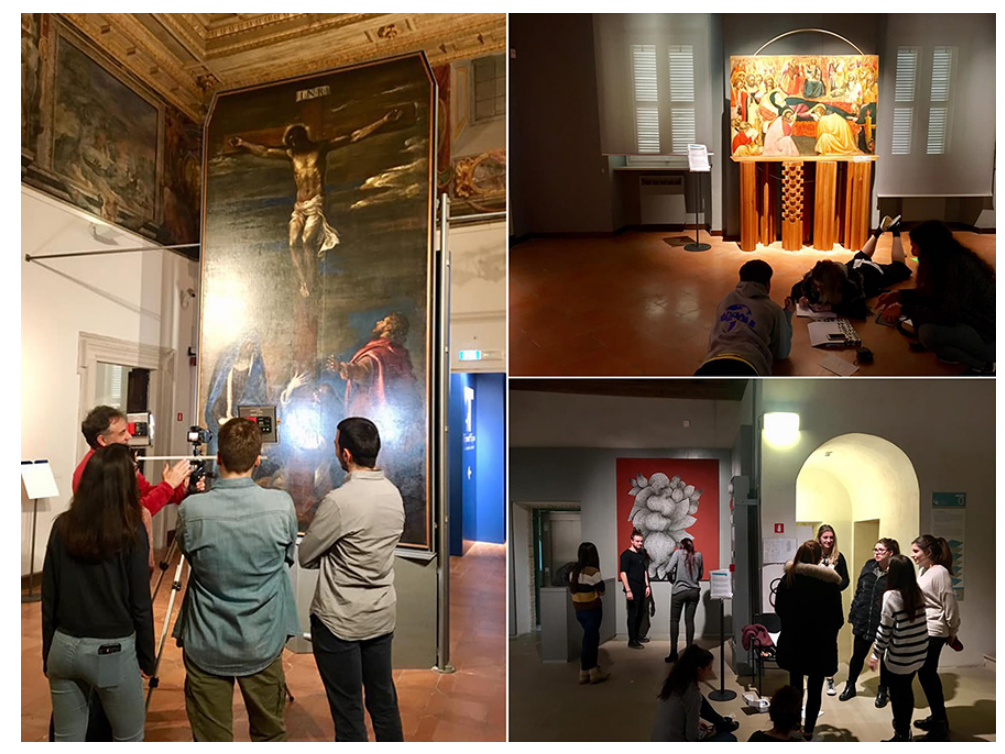


Digital solutions such as laser scanning [Pfeifer, Briese 20I4] and photogrammetry [Luhtmann et al. 20l I] offer, to the scientific community, along with the common user, the possibility of a digital 3D fruition of historical and artistic object as well as complex spaces [liménez Fernández-Palacios et al. 20 17]. They are ideal solutions because of potential and versatility to documentation, analysis, visualization and dissemination of Cultural Heritage and they are available for various educational purposes. The integration of these two techniques allows to generate photorealistic 3D models characterized by an high geometric detail, with methodologies applicable to different scales and now widely accepted as an optimal solution for the creation of digital facsimiles of objects or real environments [Clini et al. 20 I; Liang et al. 20 I8].

The use of these outputs, which have already shown enormous potential for the definition of an exact plan of monitoring, protection and maintenance of the Cultural Heritage, can be operated through different solutions; from those most commonly related to popular aspects, such as augmented or virtual reality applications [Bozzelli et al. 20 I9]; to real archives and 3D catalogues, such as digital libraries within museums [Clini et al. 2017] or made available in cloud computing on the web [Quattrini et al. 20 I8]. Another solution that allows as to enjoy these virtual models, integrating them to the narration of their intangible aspects, is offered by VT. As in [Mah et al. 2019], thanks to $360^{\circ}$ photos, VTs allow the user to visit cultural places in an immersive and interactive way, offering the possibility to load multimedia content such as texts, audio and video and exploit real-time interaction with operators involved in the provision of museum services. The wide potential of divulgation and diffusion of the $360^{\circ}$ panoramic images, which are for years a consolidated line of research [Clini, Quattrini 20l I] and a standard for large players [Proctor 20 I I], does not fail to reserve interesting developments, as demonstrated in this contribution.

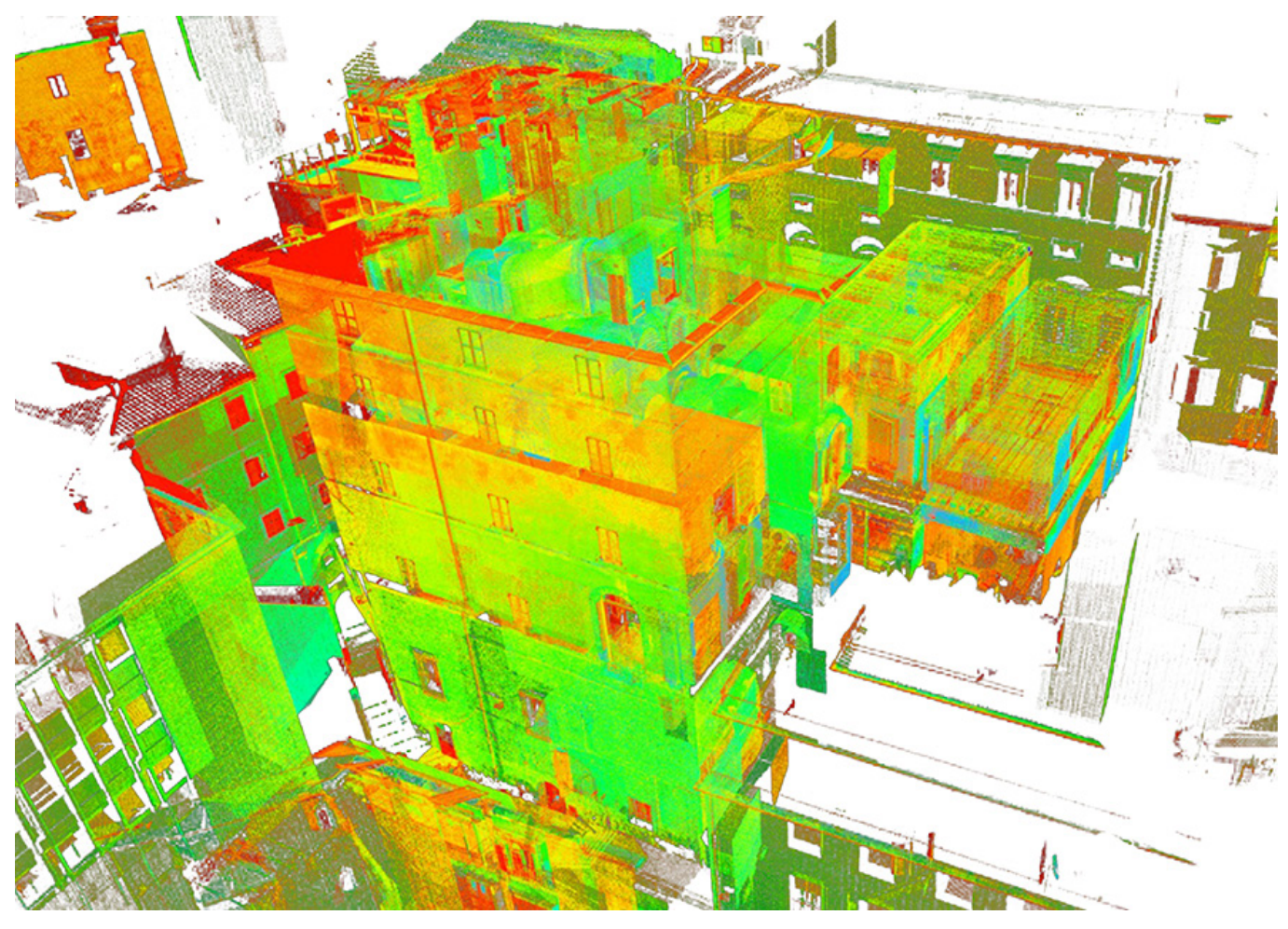


Fig. 3. Individuation of the acquisition shots made for the survey of the rooftop acquisition project and D view of the generated dense cloud.

\section{Methodology}

The Civic Art Gallery F.Podesti of Ancona: an educational lab for the digitization of the Cultural Heritage

The Architectural Survey Lab of the course of degree in Building Engineering-Architecture of the Polytechnic University of the Marche, with its field experience, integrates the lectures held in the classroom and aimed at learning the theoretical bases of this discipline. The course, in the various editions, has dislocated its activities in the main cultural places of the Marche region, in the belief that the direct comparison with the Cultural Heritage can be a concrete stimulus and a moment of responsibility for students, who will become the professionals of tomorrow.

For the academic years 2018-2019 and 2019-2020, the chosen case study is the Civic Art Gallery "F.Podesti" of Ancona. Reference in the cultural scene of the capital of the Marche region since its institution, occurred in 1884. The building that now includes his collection is the historic Palazzo Bosdari, built in the current shape already in I 400 and renovated since 1660, with strongly mannerist accents.

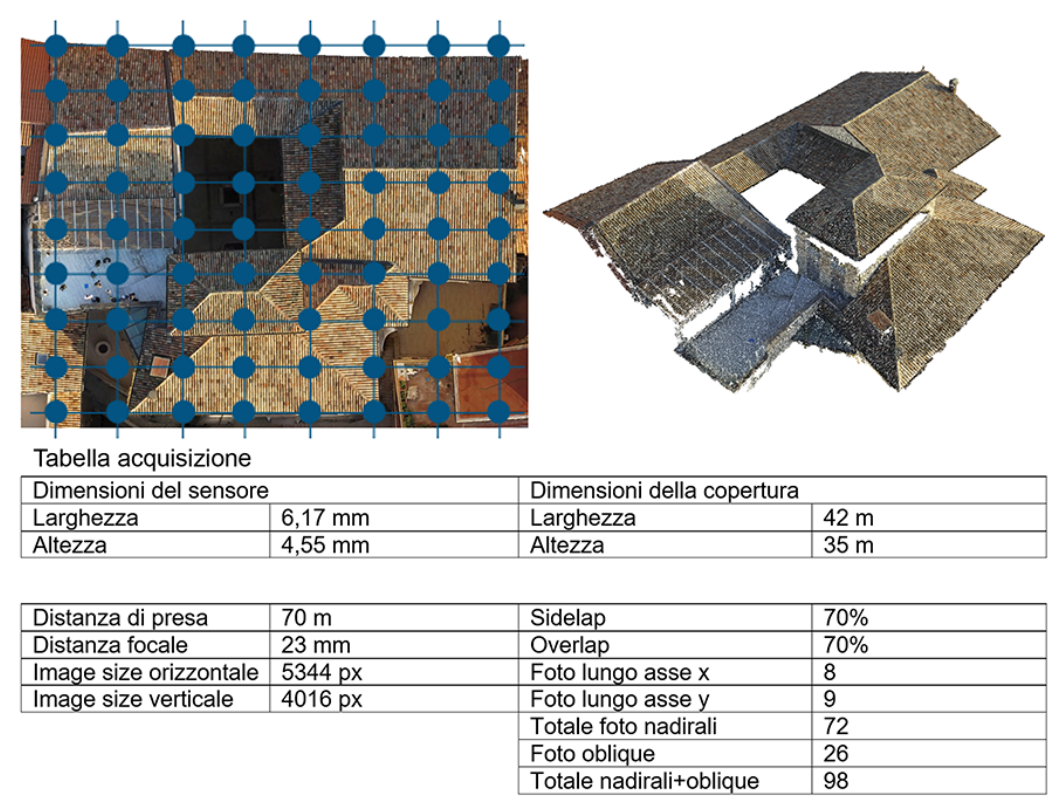

Digitize content and container

The work has foreseen a first phase of knowledge of the objects, which took place through the story of the building and the focusing on some shown works offered by art historians of the cooperative Le Macchine Celibi, which manages the Museum and has actively participated in these activities. The students, knowing the history, the characteristics and the consequent problems related to spaces and objects, were simultaneously actors and learners in the second phase planned: the digitisation by laser scanner and photogrammetry of the works assigned to them and their exhibition spaces. The main aim of each group was therefore the definition of a complete set of geometric information, useful to define a perfect digital facsimile of a portion of the building and what it contains.

In order to obtain a complete documentation of the building, I 33 scan stations were carried out using a Leica P40 Scanstation. Then integrated with $360^{\circ}$ panoramic images, made by 8 single shots with a Nikon D90 camera, equipped with $8 \mathrm{~mm}$ fisheye lens, mounted on a panoramic head and placed on a tripod in order to make it collide the nodal center with the laser sensor.To conclude the survey of the structure, the roof model was made through the aerial photogrammetric survey, using a Parrot Anafi drone. A group of students were involved in flight planning, and then conducted with the assistance of a qualified SAPR operator [2].

The activity of digitization has finally affected the works shown, in this case the students 
carried out it applying the photogrammetric technique Structure from Motion. Each group focused on those relating to the exhibition rooms that they had previously dealt with in the phase of relief of architecture. For an adequate subsequent three-dimensional reconstruction, the acquisition saw the use of a suitable lighting system, shielded with polarizing films in order to eliminate superficial reflections by the rotation of a similar filter applied to the camera lens, a Sony a9 (fig. I).

This huge amount of data was processed using different software (sw). Regarding laser scans, it was employed by using the sw Leica Cyclone.The pointclouds of each stations have been aligned obtaining a single discreet model, describing all the spaces of the Civic Art Gallery, constituted from beyond 9 billions of points (fig. 2), coloured by resorting to $360^{\circ}$ panoramic images, processed by using the sw Ptgui, with a final alignment error of the order of the centimetre.

The elaboration, inside the software Agisoft Photoscan, of the drone acquisitions (fig. 3) has allowed integrating such pointclouds with those relating to whole building. (fig. 4).

The final output was decimated in order to be easily managed by groups of students for the purpose of extrapolation of plans, elevations and sections of the building. (fig. 5)

For the different works, the photographic shots, acquired in raw format, were edited thanks to the sw Adobe Cameraraw, and then processed in Photoscan obtaining 3D models with a maximum alignment error estimated at I mm (fig. 6).

The last step of this digitization process was the reunion of content and container: each works was brought into the spatial reference system of the building's pointclouds by associating the coordinates of points known from the laser scans to the correspondents obtained by photogrammetric process. The result is the exact geometric reproduction of the building, integrated with models of the works of high detail and especially characterized by high-resolution photographic textures (fig. 7).

Fig. 4. Result of the integration of the pointcloud taken by laser scanning and the one of the rooftop obtained by photogrammetric drone acquisition.

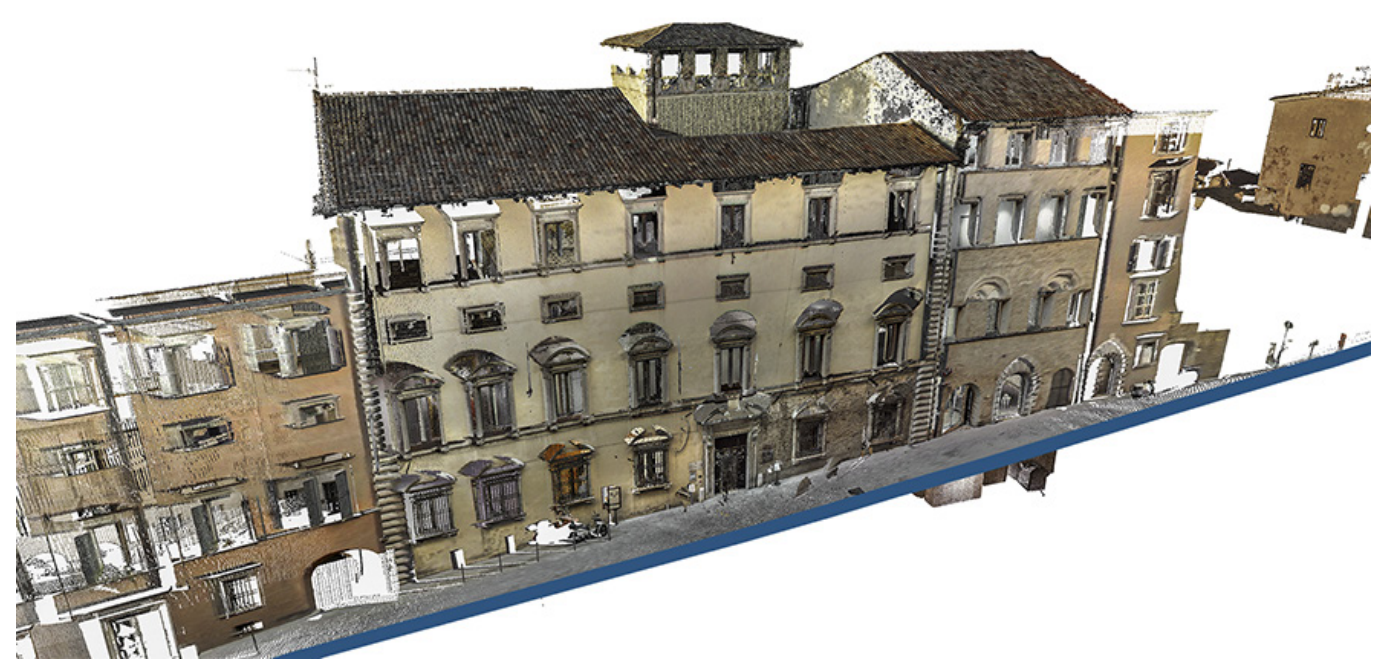

A virtual tour to comunicate Cultural Heritage

The results of the teaching experience just described were further enhanced by the activation of a joint reflection between the researchers of the Polytechnic University of Marche and the interlocutors of the Museum.

The interdisciplinary reflection has led the working group to the introduction of a wider project aimed at creating a digital product with strong interactive and experiential potential. 

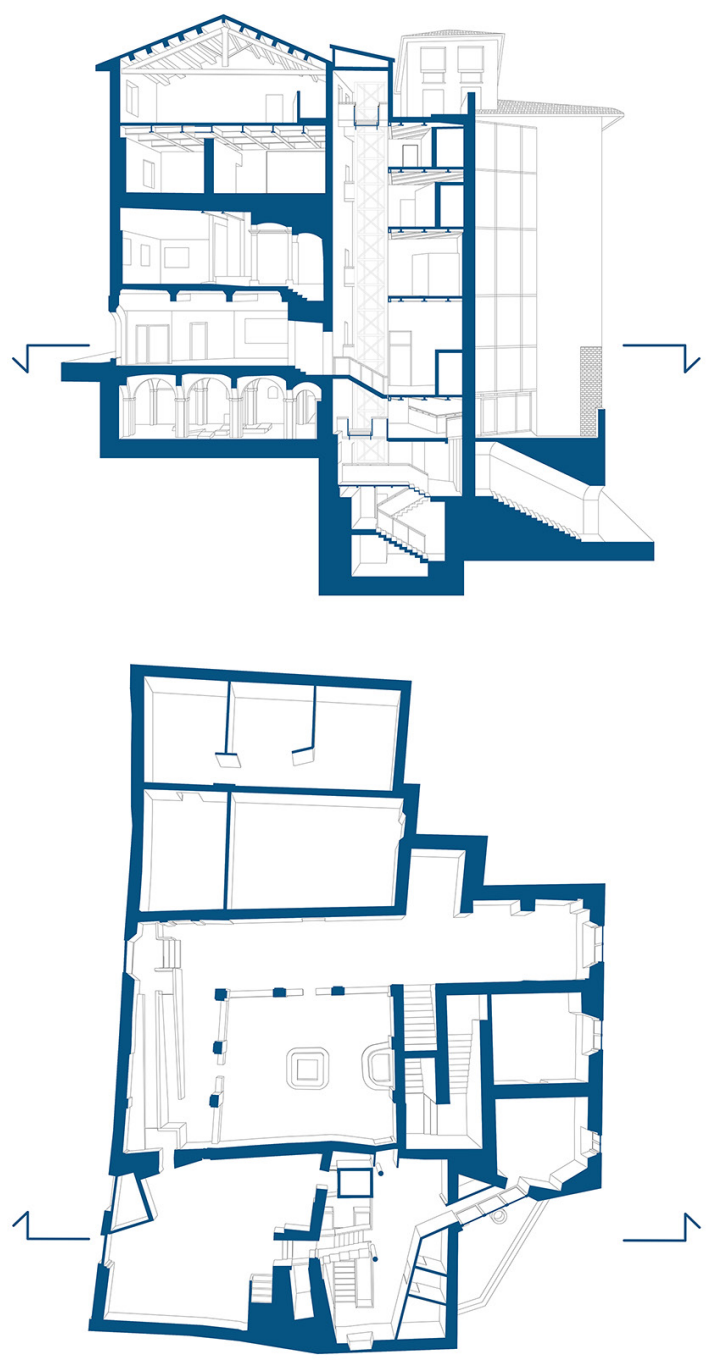

The added value of this experience can be linked to a twofold contribution:

- The first concerns the activation of the dialogue between museum and technology. In the museum sector, in fact, the conscious perception of the potential connected to the world of technological tools is very lacking. This experience has therefore created a bridge between the two sectors, with the start of a long-term design that sees the enrichment of the student path and at the same time the connection of the University to the territory in support of the Cultural Heritage.

- The second concerned the creation of an operative tool available to the museum. This tool makes it possible to involve virtual visitors and can be used for new forms of digital use and cataloguing of the heritage.

The design approach adopted has therefore aimed at the creation of a prototype of an "empathic digital museum" [Vitale 20 I3] according to the concept of putting the visitor at the centre of the design, it follows a precise scheme:

- study the visitor of the museum;

- create the conditions to motivate people to interact with the museum heritage;

- activate environments to enable participation through the care of different languages for each identified target audience.

These premises made sure that the project turned its attention to the museum experience. This is optimal when there is focus and attention to the processes in place, emotional interest, satisfaction and joy, and then motivation because in this state the user is conscious about what he is doing, and it is the basis and reason for his action. 
Fig. 6. Photogrammetric modelling of the Pala Gozzi, first dated work by Tiziano.

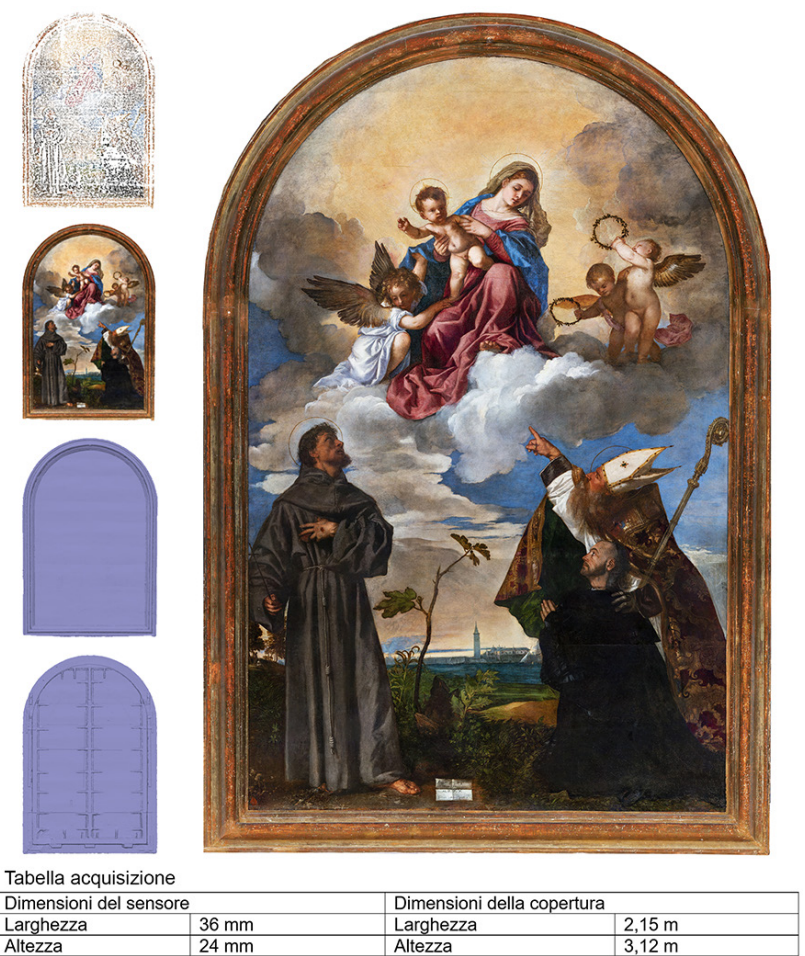

Larghezza
Altezza $24 \mathrm{~mm}$ Altezza

\begin{tabular}{|l|l|l|l|}
\hline Distanza di presa & $1,5 \mathrm{~m}$ & Sidelap & $70 \%$ \\
\hline Distanza focale & $50 \mathrm{~mm}$ & Overlap & $70 \%$ \\
\hline Image size orizzontale & $6000 \mathrm{px}$ & Foto lungo asse $\mathrm{x}$ & 7 \\
\hline Image size verticale & $4000 \mathrm{px}$ & Foto lungo asse y & 15 \\
\hline
\end{tabular}
Totale foto

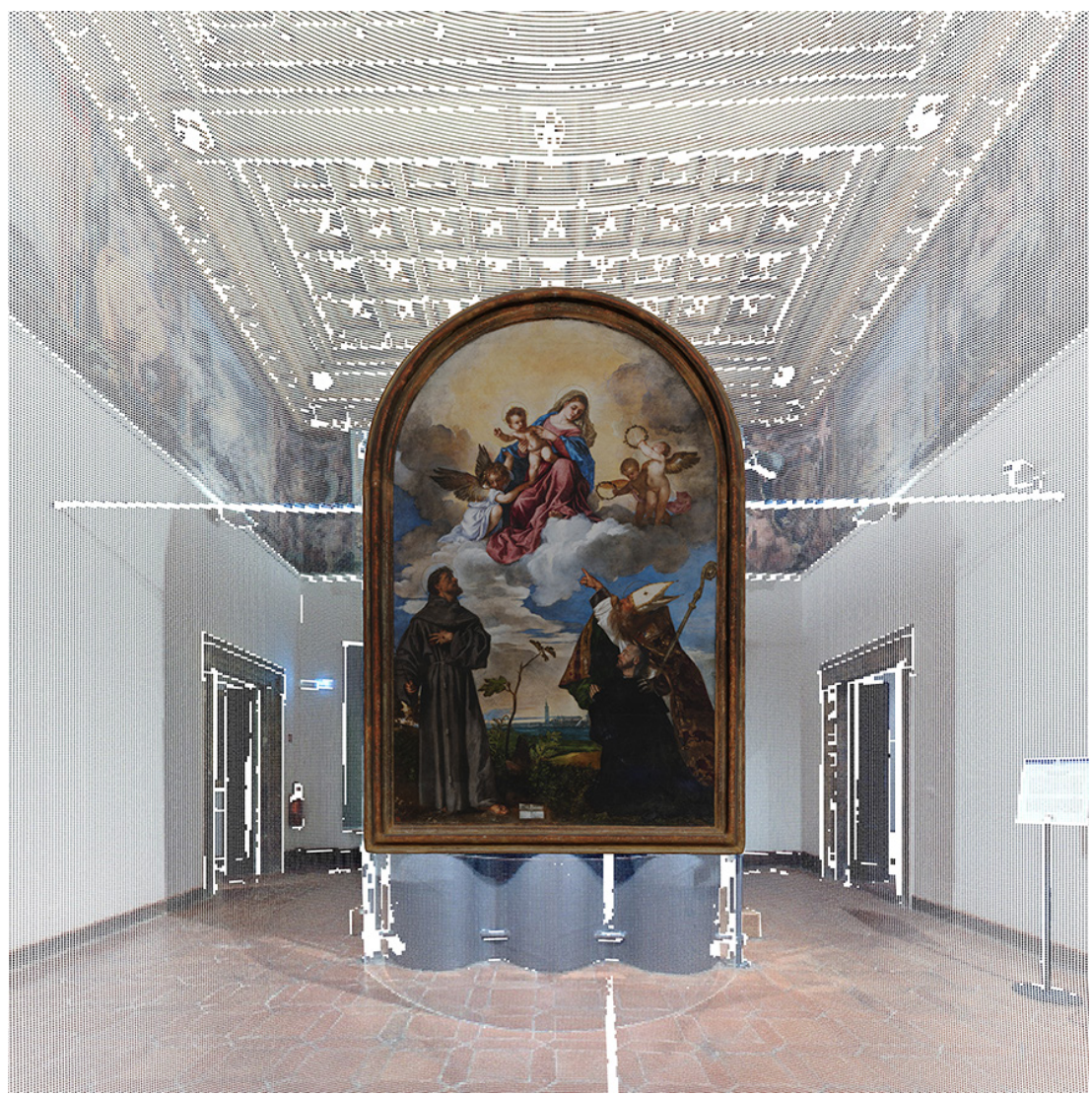

Fig. 7. Integration of the pointcloud of the building with the mesh model of the pieces of art. A view of the Pala Gozzi on display in the Zampetti 
At the base of the fruition is therefore the motivation that can be connect to 4 fundamental drivers according to Gerri Morris [Morris 2004]:

I) The social aspect as a form of entertainment;

2) The intellectual aspect for academic and professional purposes;

3) The emotional aspect linked to the aesthetic experience;

4) The spiritual dimension that insists on creativity and contemplative processes.

A good museum, especially a virtual one, must not discourage the visitor and must be easily accessible, with comprehensible indications and useful information, designed for every type of public [Branchesi et al., 20 16]. In this regard, the VT realized has put in place a series of models to experiment how to achieve a proper interaction with the public, with the intent to propose the dynamics of direct experience of the Cultural Heritage (fig. 8).

The VT, developed starting from the potential offered by the software Pano2vr, allows the user to move from one room to another thanks to a map of the Art Gallery or by selecting directly a work of his interest. In each room a welcome text introduces the visitor to the paintings shown and by clicking on them he can load information, high-resolution images and 3D models (fig. 9). Moreover, by wearing a virtual reality viewer, it is possible to start a completely immersive experience for a three-dimensional reproduction of spaces and works (fig. 10).

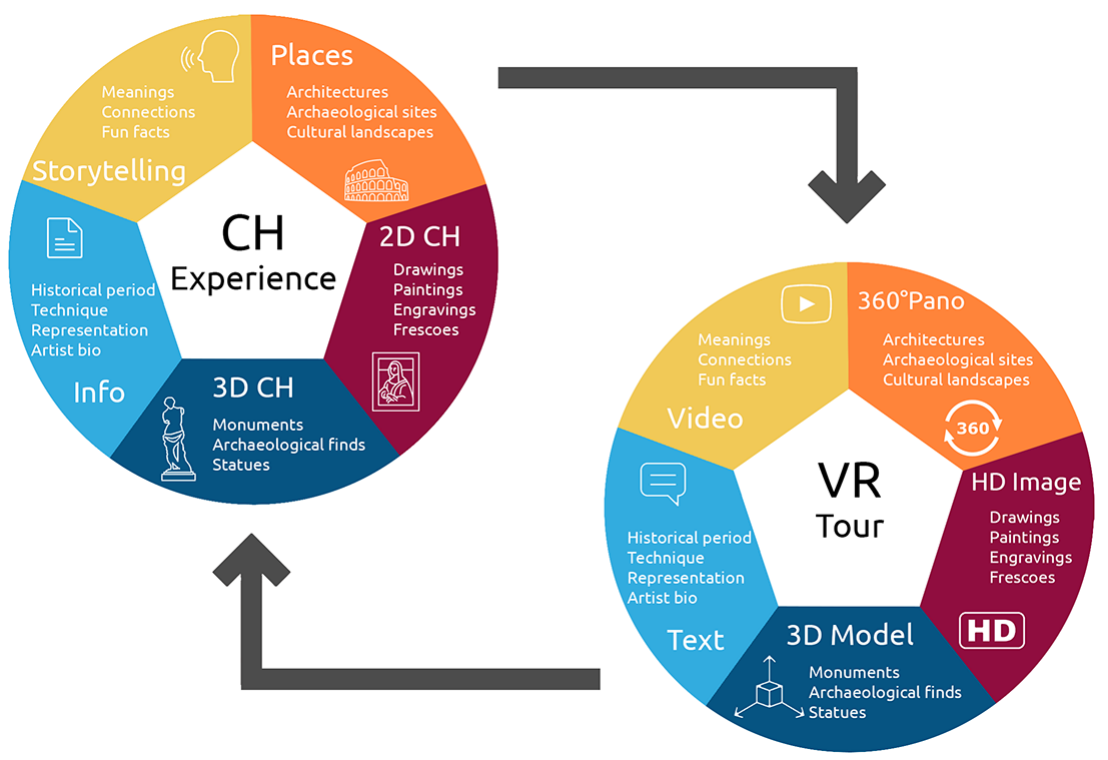

\section{Conclusioni and future work}

The project started as a laboratory of permanent experimentation that will allow working on VT with the aim of enhancing and adding tools aimed to enhance user interaction.

Here are some examples of implementation, structured in reference to specific themes that can be systemized:

- Accessibility: the study and implementation of special mediation tools such as texts with high readability, audio descriptive and narrative designed for different types of users.

- Entertainment: will be defined a schedule related to the use of the virtual space characterized by guided tours and exhibitions with paintings that otherwise would hardly have been exposed in real size.

- Fruition: will integrate proposals aimed at exploring individual works with the addition of thematic cards. An example is that of the restoration aspects that would offer the possibility of investigating the material reality of the paintings. 
Fig. 9. Virtual Tour gives us information about different rooms and focus on each piece of the collection, taking advantage of $H D$ images and $3 D$ models.
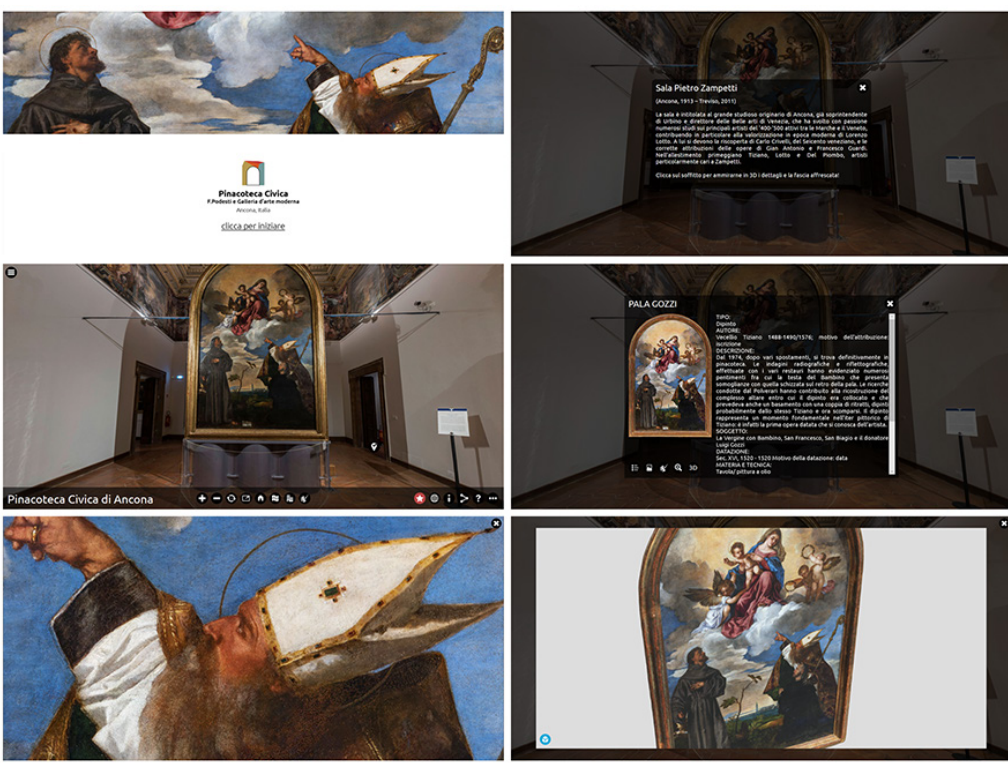

The great challenge of this approach is the demonstration of how technology can enter the world of the fruition of cultural heritage by creating new tools that, starting from a correct digitalization of heritage as a new form of protection and conservation, implement the educational function by creating a new systems of interaction and possible services aimed at the new virtual public.
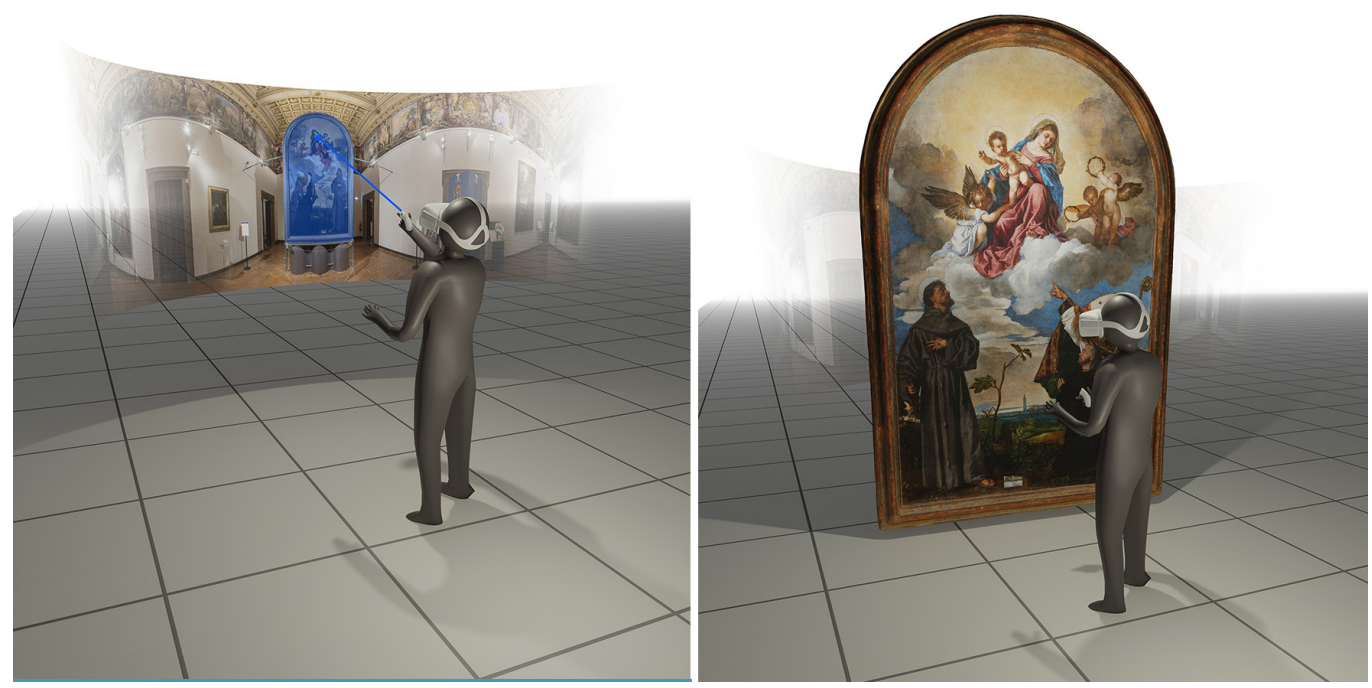

Notes

[I] The teaching activity was developed within the Architectural Survey Lab of the degree course in Building EngineeringArchitecture of the Polytechnic University of Marche Region, Prof. Paolo Clini.

[2] Dr. Ing Gianluca Gagliardini conducted the drone acquisition; he is a professional laser scanning and photogrammetric expert and teaching assistant of the course. 


\title{
References
}

Bozzelli Guido, Raia Antonio, Stefano Ricciardi et.al. (2019). An integrated VR/AR framework for user-centric interactive experience of cultural heritage:The ArkaeVision project. In: Digital Applications in Archaeology and Cultural Heritage, Vol. 15.

Branchesi Lida, Curzi Valter, Mandarano Nicolette (20 I6). Comunicare il museo oggi. Dalle scelte museologiche al digitale. Milano: Skira editore.

Clini Paolo et.al., (2019). The integrated survey of narrow spaces and underground architecture:The case study of Campana caves bas-reliefs. In: ISPRS Annals of the Photogrammetry, Remote Sensing and Spatial Information Sciences. S.I.: s.n.

Clini Paolo, Nespeca Romina, Ruggeri Ludovico (2017). Virtual in real. Interactive solutions for learning and communication in the national archaeological museum of Marche. In: International Archives of the Photogrammetry, Remote Sensing and Spatial Information Sciences - ISPRS Archives. S.I.: s.n., p. 647-654.

Clini Paolo, Quattrini Ramona (20I I). Le panoramiche sferiche per il rilievo e la comunicazione dell'architettura, un nuovo approccio alla realtà virtuale speditiva. In: Sardo Nicolò (a cura di). Metodologie integrate per il rileivo, il disegno, la modellazione dell'architettura e della città. Roma: Gangemi Editore.

Jiménez Fernàndez-Palacios Belen, Morabito Daniele, Remondino Fabio (2017). Access to complex reality-based 3D models using virtual reality solutions. In: Journal of Cultural Heritage.Vol. 23, p. 40-48.

Liang Huilin et al. (20/8). The integration of terrestrial laser scanning and terrestrial and unmanned aerial vehicle digital photogrammetry for the documentation of Chinese classical gardens - A case study of Huanxiu Shanzhuang, Suzhou, China. In: Journal of Cultural Heritage, nr. 33, pp. 222-230.

Luhtmann Thomas, Robson Stuart, Kyle, Harley lan (201 I). Close Range Photogrammetry: Principles, techniques and applications S.I.: s.n.

Mah Osten Bang Ping et al. (2019). Generating a virtual tour for the preservation of the (in)tangible cultural heritage of Tampines Chinese Temple in Singapore. In: Journal of Cultural Heritage, nr. 39, pp. 202-21 I.

Morris Gerri (2004). It's a vision thing: <https://www.culturehive.co.uk/wp-content/uploads/20 I 3/09/Its-a-vision-thing...GerriMorris.2004.pdf. $>$.

Parlamento europeo e Consiglio dell'Unione (2017). Decisione (UE) 2017/864 del Parlamento europeo e del Consiglio del 17 maggio 2017 relativa a un Anno europeo del patrimonio culturale (20।8). Unione Europea: Gazzetta ufficiale dell'Unione europea: <https://eurlex.europa.eu/legalcontent/IT/TXT/PDF/?uri=CELEX:320 I7D0864\&from=EN>.

Pfeifer Norbert, Briese Christian (20 I 4). Laser scanning - principles and applications. In: GeoSiberia 2007 - International Exhibition and Scientific Congress. S.l.: s.n.

Proctor Nancy (20 I I).The Google Art Project:A New Generation of Museums on the Web? In: Curator:The Museum Journal.

Quattrini Ramona, Frappicini Nicoletta, et Nespeca Romina (20I8). ARCHEOGate: un portale web per la catalogazione e la fruizione dell'archeologia delle Marche. In: Salerno Rossella (ed.). Rappresentazione materiale/immateriale-Drawing as (in)tangible representation. $40^{\circ}$ Convegno internazionale dei docenti delle discipline della rappresentazione. Milano I5- I7 settembre 20 I 8 : Milano: Gangemi Editore, pp. I349- I358.

Vitale Giovanna (20।3). Design di sistema per le istituzioni culturali. Il museo empatico. Bologna: Zanichelli <http://www.aiap.it/ libreria.php?|D=6227>.

\author{
Authors \\ Paolo Clini, Università Politecnica delle Marche, p.clini@univpm \\ Ramona Quattrini, Università Politecnica delle Marche, r.quattrini@univpm.it \\ Renato Angeloni, Università Politecnica delle Marche, rangeloni@pm.univpm.it \\ Mirco D'Alessio, Università Politecnica delle Marche, m.dalessio@pm.univpm.it \\ Laura Lanari, Macchine Celibi soc. coop. , lauralanari@museieducativi.it
}

To cite this chapter. Clini Paolo, Quattrini Ramona, Angeloni Renato, D’Alessio Mirco, Lanari Laura (2020). La Pinacoteca Civica F. Podesti di Ancona: un laboratorio didattico per la digitalizzazione del Patrimonio/The Civic Art Gallery of Ancona: an educational laboratory for the digitization of Cultural Heritage. In Arena A., Arena M., Brandolino R.G., Colistra D., Ginex G., Mediati D., Nucifora S., Raffa P. (a cura di). Connettere. Un disegno per annodare e tessere. Atti del $42^{\circ}$ Convegno Internazionale dei Docenti delle Discipline della Rappresentazione/Connecting Drawing for weaving relationships. Proceedings of the 42th International Conference of Representation Disciplines Teachers. Milano: FrancoAngeli, pp. $1974-1993$. 